\title{
Forced Migration: The Case of Armenia - 1915 and beyond
}

\author{
Seda Gasparyan \\ Yerevan State University
}

\begin{abstract}
The article aims to discuss the question of deportations as part of the genocidal process, accomplished in western Armenia by the Turks particularly in 1915. Allegations intentionally pushed forward by the Turkish rulers of the period claiming that Armenians were treacherous separatists served as a "well-grounded" justification for them to administer the wholesale deportation of the Armenian population first from eastern and south-eastern provinces, then the capital city Constantinople and other major cities of the empire. The investigation of documented facts as well as the results of other researches shows that the idea of the deportations was conceived and promulgated in 1915 to mask the pre-planned genocidal actions which had come into full swing long before. The Ottoman authorities were somewhat taken aback after they received the joint declaration issued by Great Britain, Russia and France laying the responsibility of the horrendous actions against humanity and civilization taking place in Turkey to the charge of the members of the Ottoman government. They hoped the Deportation Law could rid them of responsibility.
\end{abstract}

\section{Introduction}

Today the world is changing so dramatically, and it has become so sensitive to any misdeed that every effort to make it more balanced and achieve mutual understanding should be appreciated and encouraged. The only things we need are good will and presence of morality, particularly when our judgements concern genocides against humanity. The Armenian Genocide is a case in point.

It is well known that April 24 has long been established by the Armenian people, as well as the progressive part of the international community as a symbolic day for commemorating the one and a half million innocent Armenian victims ferociously slaughtered by Turks or savagely forced into the path of death marches. This venomous attitude of Turks towards Armenians and the Christian population of the region at large, the roots of which go back to a period centuries ago when Turks took over the Armenian plateau, can basicly be accounted for by political and religious reasons, and vain are the efforts of those who try hard to present the relations of Armenians and Turks in rosy colours and explain the occurrence of the Armenian Genocide by outer factors and World War I in particular (Suny 1993). Investigations have shown that Turks understood the necessity of ensuring their supremacy in the occupied territories, and this actually seems to be the reason why they not only consistently sought to bring 
Armenians and other Christian nations to their knees, but also to change the ethnic picture of Western Armenia through mass killings and turning the indigenous peoples into Turks. Parallel to this, the rulers of both the Ottoman Empire and the Republic of Turkey also realized the strategic importance of toponyms and carried out consistent policy of distorting, Turkifying and appropriating the Armenian toponyms. Investigations in this field have long established that having the aim of assimilating the toponyms of the conquered territories they translated them into Turkish, transformed the local dialectal place names making them sound like Turkish word forms, pushed forward etymological misinterpretations or just renamed them. An obvious case in this last point is the replacement of the toponym "Armenia" for the invented term of "Anatolia" by the government of Sultan Abdul Hamid II. This, as they thought, would give them a chance to make clear that there existed no Armenian question, for there was no Armenia at all (Ayvazyan 1998; Sahakyan 2011; 2015). But the fake and fabricated nature of the term "Anatolia" is obvious for, "Eastern Anatolia" is nothing else but the forgery of two monosemantic words both meaning "east." Thus, "Eastern Anatolia" meaning "Eastern East" sounds more than absurd.

There can be no doubt, except for some Turkish and pro-Turkish sources, that Western Armenia was the cradle of Armenians where they had originated and lived for centuries (Marshal Lang 1980), and it was from the XI century AD on that, as presented in Webster's Third New International Dictionary (1981:2465), the racially mixed nomadic tribes of Turks who are held to have risen in the Altai mountains and western Siberia, moved to Asia Minor and the neighbouring territories, enslaved Armenians who, although the owners of the land, unfortunately had no statehood at that time. They also enslaved the other Christian population living on those territories, settled themselves there and gradually declared themselves to be the owners of the land.

When the Russo-Turkish war (1877-1878) came to its end, and Turkey was happy to get the major parts of the Western Armenian provinces, it, however was obliged by the peace treaties of San Stefano and Berlin (1878) to improve the living conditions of Armenians by carrying out some reforms. However, this decision remained on paper, and Turkey gave birth to its scheme of annihilating Armenians, thus planning to remove Armenians from its way to the realization of its "grand idea" of Great Turan and provide religious and territorial continuum for the Islamic and Turkic nations of the region (Khurshudian 1995). Christianity in general and Armenians with their strong conviction for Christian traditions were considered to be a serious geographical and religious obstacle on this way. Thus, the Turkish authorities were convinced that the solution of the Armenian question should be radical: instigation of various assaults, plundering and looting of the Armenian population, mass slaughters, and massacres, forced migrations, etc. - all leading to radical extirpation of a nation from its native land.

This vicious policy adopted in the Hamidian period was later - at the beginning of the XX century - inherited by the Young Turks, and although promises of establishing 
ethnic and social equality were quite often given by the Young Turks, the latter didn't even bother about Berlin Congress provision (1878) and continued to develop their genocidal scheme.

\section{The Idea of Deportations as an Excuse for Annihilation}

The Yeghern, initiated back in the Hamidian period and escalated later by Republican Turkey continues to give pain to the Armenian people, for the perpetrators do not even repent, let alone return Armenians what they took from them and still go unpunished. Moreover, when these horrendous genocidal events aimed at exterminating a whole nation are veiled under the cover of mere deportations, this is obviously violation of morality.

Nevertheless the Turks pretend to be convinced that those events were mere deportations on the grounds that the Ottoman Empire's desperate conditions, desperate because the War forced upon them, as they tend to explain it up to this day, made the authorities take the decision of displacing Western Armenians because of poverty, hunger and particularly military actions that were stressed out as the basic reason for the deportations. But the Genocide executed by the Turkish government in western Armenia and the deportations as part of the general scheme had absolutely no direct connection with the hostilities of the World War. This is borne out by the documents of the trial of the Young Turks which reveal that the scheme of extermination of Armenians was made in advance by the "Union and Progress" Party. There is evidence of that in the arguments put forward by Rifat Melvanzade, too, who writes that the "Union and Progress" Party was determined to carry out its horrendous plan of extermination (Melvanzade 1929), which meant to divest the territories of their Christian population, Armenians in particular whom they were quite decisive to destroy and not to leave anyone alive. Another evidence of this determination are the ordermessages of the Interior Minister of the Ottoman Empire in those days Talaat pasha, who stated that the Armenocide should be executed with no hesitation or objection to his demands and advised to include women and children, old and young, however tragic the means might be ${ }^{1}$.

\section{The Implementation of the Scheme of Deportations}

The forced drive started after a top secret conference which gave a general guideline for the execution of the Genocide scheme. The five chief figures, in fact, top decisionmakers of Turkey (Talaat, two physicians-politicians - Sakir and Nazim, Canbolat who was the chief national security and Colonel Seyfi who was the head of Intelligence Department at the Ottoman General Headquarters) wrote the bloody pages of the Turkish history with the help of the Turkish mob, Kurdish bands and of gangs of criminals released from prison on purpose. The scheme was extended to all of the Empire's Armenian population. This was a methodically pre-planned scheme of extermination, according to which the first and effective step to wipe out Armenians 
was to behead the nation by murdering its intellectuals. The next step was to set up a Special Organization for deportation. Both official and non-official "resources" of Turkey were put to action. Convicts, intentionally released from prisons, raided on Armenian villages and displaced the population. Mass deportations started in May, 1915 and soon the provinces inhabited by Armenians were cleaned up of their Armenian population (Melkonyan 2015). Besides speculating upon the factor of the World War, they also put forward other reasons such as treasonable acts, separatism, etc. which, as the Ottoman authorities presented, made them order the wholesale deportation of the Armenian population of the eastern and southeastern provinces of the Empire.

In this connection the German Embassy Charge von Neurath informed Berlin on November 12, 1915 that according to a reliable source the Turkish Government has, contrary to all assurances, decided to deport the Armenians of Constantinople too.

On December 7, 1915 German Ambassador Metternich, too, informed Berlin that 4000 Armenians had recently been removed from Constantinople and that the total number of those deported from the Ottoman capital up to that time had reached 30000 and that gradually a clean sweep will be made of the remaining 80000 Armenians of the Ottoman capital.

The procedures of the gradual liquidation of the Armenian population of the capital is also presented in the eye-witness accounts of German correspondents stationed in Istanbul. In a confidential report, the correspondent of Kölnische Zeitung, a major German newspaper, presents some details of the procedure: they concentrated first on the provincials, then the singles and then the married ones with their families. The correspondent even ridicules the government's claim that only those suspected of disloyalty were arrested, but then he mentions as a witness that the most harmless people were being deported in a systematic way, and the two caretakers of his household, whom he personally knew very well, were among them. All this was carried out by reliable Turks who were in full touch with the police and knew very well the scheme of those deportations (Dadrian 1995:291).

As can be deduced from this and numerous other documents, official and personal correspondence, evidence corroborated by reports received from Americans, Danes, Germans, Italians, etc., the deportations were just a disguise to mask the pre-planned annihilation of the Armenian population. The vast majority of the deportees perished through a variety of direct or indirect atrocities perpetrated during the death-marches of the deportees.

\section{The Temporary Law of Deportation in Action}

The first step taken in the deportation period was the general mobilization at the beginning of August, 1914 launched by Turkey with the assistance of German staff officers. They accomplished the mobilization in three stages: first male Armenians from 20 to 45 years of age, then from 15 to 20 , then finally from 45 to 60 . In fact, they were not mobilized to be sent to the army, but under the pretext of mobilization the majority 
of them were killed. The evidence provided by Ambassador Morgenthau testifies the use of mobilized Armenians as pack animals. He writes: "Army supplies of all kinds were loaded on their backs, and stumbling under the burdens and driven by the whips and bayonets of the Turks... almost waist high through snow. If any stragglers succeeded in reaching their destination they were not infrequently massacred" (Morgenthau 1918:302).

A month later on September 6 the provincial authorities were instructed by the Interior Ministry, to watch the Armenian political community and leaders very closely, and soon the Armenian provincial population was utterly stripped of their accumulated goods which went under the general category of "supplies and provisions for the Army." But as Taner Akcam observes, under the pretext of searching for arms and collecting provisions for the Army, Turks plundered the churches, outrageously robbed the sacred utensils, beat the priests into insensibility, thus provoking peaceful Armenians into extreme acts of self-defense in order to provide an excuse for annihilation (Akcam 2006).

The next stage in this process was the order of the Interior Ministry on April 24, 1915 which, as already mentioned, authorized the arrest of all Armenian political and community leaders who were suspected of anti-Ittihad or nationalistic sentiments. But as the sources inform, this was not the case at all, for the majority of them were not even involved in politics.

The last stage of this process was the deportation which was officially promulgated in the press on May 27, 1915. The occurrence of the so-called Temporary Law of Deportation empowered the authorities to administer the deportation of the Armenian population of Turkey. But when on May 24, 1915 Great Britain, Russia and France issued a joint declaration indicating that Turks and Kurds massacred the inoffensive Armenian population with the approval and assistance of the Ottoman government, and that the Allied countries were full of determination to hold all the members of the Ottoman government personally responsible for those new crimes of Turkey against humanity and civilization, the authorities were somewhat taken aback. However it did not stop their actions of annihilation. The only thing that bothered them was to avoid responsibility, and this made them conceive the deportation plan and present it as Temporary Law of Deportation. In November 1918 the Temporary Law of Deportation was however cancelled at a session of the post-war Ottoman Parliament on account of its unconstitutionality, but the victim population had already been eliminated and prevailingly massacred.

On June 10, 1915 a supplementary law was enacted which instructed how to register the properties of the deportees, how to guard them safely and how to remit them to the owners if they return after the war. Another Temporary Law promulgated on September 26, 1915 administered the handling of the debts, credits and assets of the deportees. The Turkish Government, however, knew very well that the deportees would never come back. So there could be no question of remitting the properties to the real owners, for 
the majority of them had been massacred, and those who had somehow managed to avoid the mass killings and escaped, would never choose to go through the horrendous sufferings again.

As presented by Vahakn Dadrian, reacting to this Temporary Law disposed of the deportees' goods and properties, the Austrian Military Plenipotentiary dismissed the whole thing as a comedy, and when the Ottoman authorities presented it to the German Foreign Office, Arthur von Gwinner - the director of the Deutsche Bank sarcastically mentioned that several articles included in the Law might well be compressed and formulated in two points: 1) "All goods of the Armenians are confiscated" and 2) "The government will cash in the credits of the deportees and will repay (or will not repay) their debts" (Dadrian 1995:222, 231).

In different sessions of the Senate beginning from September to December, 1915, Senator Ahmed Riza raised his voice against this Law of confiscation, tried to prove its unconstitutionality, urged his fellow legislators to consider the sufferings of the wretched deportees, those who were still alive and wandering around in the mountains. He thought it unlawful to designate the Armenian assets and properties as "abandoned goods" for he knew it very well, and everybody knew, that Armenians had not abandoned their properties voluntarily. They were forcibly, compulsively removed from their domiciles and exiled. Referring to his conscience and the Constitution as well, Ahmed Riza expressed the belief that nobody, including the government, was permitted to sell or confiscate the property of the Armenians. After long debates Senator Ahmed Riza managed to achieve the inaction of the Law and on January 8, 1920 the Law was annulled. Nevertheless on September 14, 1922 the Kemalists reversed the annulment (Refik 1919:41-42).

The Swiss historian S. Zurlinden, referring to a "knowledgeable German" source, states that what really happened was an expropriation carried out on the greatest scale against 1,5 million citizens. In the words of the American consul Jackson, it was a "gigantic plundering scheme as well as a final blow to extinguish the Armenian race (Dadrian 1995:223).

Ambassador Morgenthau identifies the real purpose of the deportation as robbery and destruction. He believes, it represented a new method of massacre which, as they saw, would be beneficial for them financially as well. When the Turkish authorities gave the orders for the deportations they were merely giving the death warrant to a whole race. Ambassador Morgenthau believes they understood this well, and in their conversation with him they made no particular attempt to conceal the fact. Moreover, at one of his meetings with Talaat the Ambassador observed the Interior Minister's uncovered frenzy against Armenians and heard his impudent boast about having left no Armenians in Bitlis, Van and Erzerum: "I have accomplished more toward solving the Armenian problem in three months than Abdul Hamid accomplished in thirty years" (Morgenthau 1974:71). 


\section{The Actual Reasons for Treating Armenians and}

\section{other Christian Population like that}

With all this and numerous other reliable pieces of information at the back of our mind we tend to raise the natural question about the reason why the Armenians and other Christian population were treated like that. The opinions expressed in official papers, correspondence, diary remarks, etc. about Armenians have always been positive. Ambassador Morgenthau's contemplations about Armenians presented in his book "The Murder of a Nation" demonstrate his estimation of the Armenian people:

"In the north-eastern part of Asia Minor, bordering on Russia, there were six provinces in which the Armenians formed the largest element in the population. From the time of Herodotus this portion of Asia has borne the name of Armenia. The Armenians of the present day are the direct descendants of the people who inhabited the country three thousand years ago. $<\ldots>$ There are still undeciphered cuneiform inscriptions on the rocky hills of Van, the largest Armenian city, that have led certain scholars ... to identify the Armenian race with the Hittites of the Bible. $<\ldots>$ For ages the Armenians have constituted the most civilized and most industrious race in the eastern section of the Ottoman Empire. $<\ldots>$

Everywhere they are known for their industry, their intelligence, and their decent and orderly lives. <..>With the Greeks, the Armenians constitute the economic strength of the empire.

(H. Morgenthau "The Murder of a Nation”, p. 16-17)

As described in the report by Hans von Wangenheim, the Ambassador of Germany to Constantinople to Chancellor Bethman Hollweg on July 7, 1915, Armenians were a hard-working and intelligent people and with their industry and gift of creativity had made a significant contribution to the country's economy. In the same report by Wangenheim we can also see quite clearly that it was the Turkish side that put a mark of hostility between themselves and, in Interior Minister Talaat's terms, the "interior enemies," i.e. the local Christians.

One Turkish naval captain, attached to the Turkish War Office, informed, and this information is referred to in the book Iki Komite Iki Kital (Two Commitees and Two Massacres) by Ahmet Refik, that in order to justify the enormous crime of the Armenian Genocide the propaganda material prepared by the War office included statements about the Armenians being in league with the enemy and about their plans to launch an uprising in Istanbul and help the enemy to capture Istanbul. Ahmet Refik confirms in his memoirs that the Interior Minister Talaat kept repeating this charge of an imminent Armenian uprising to make the anti-Armenian measures taken by him 
personally and the Turkish authorities at large look preemptive in nature and as borne out of military necessity (Refik 1919).

This standpoint of using the context of World War I to disguise the actual intent of the Ottoman authorities to carry out their pre-planned scheme of exterminating Armenians and the Christian population at large was advocated not only by Ittihadist leaders but, in fact, by the Ottoman Government in general. This view has been and is still being advocated by pro-Turkish scholars, by ersatz-historians who, for one reason or another, having appeared in the web of the anti-Armenian propaganda, yield to Turkish-born ideas and willingly or unwillingly contribute to the Turkish promotion. In this connection one can be referred to the works by American historians Mr. and Mrs. Shaw, also G. Lewy, R. Suny, who are active proponents of this viewpoint. These authors, implementing their strategy of persuasion and trying in every possible way to seem to be standing on neutral ground, interpret the unpardonable barbaric behaviour of the Ottoman government in a very euphemistic manner trying to convince that the Turkish authorities were aptly inclined to improve the unstable conditions Armenians were in, but unfortunately, they were not farsighted enough to foresee their incapability of keeping an eye on the process of the deportation. They also pretend to believe that, despite its good will, the Ottoman government did not have enough financial resources either to accomplish the migration of the Armenian population properly. But this sounds absurd, as everybody, more or less acquainted with the Armenian question, knows that the Genocide of Armenians was a pre-planned scheme, and even some Turkish authors (Deringil, Berktay, Akcam, etc.) show that the mass deportation and destruction of Armenians in many settlements of Western Armenia and Asia Minor at large had absolutely nothing to do with the military actions. Quite on the contrary, as they state, Armenians were often being driven from relatively safer regions to more hostile places (Akcam 2006; Turkery turkeri masin 2011).

Referring to crucially important records and facts and investigating them, the Turkish scholar Taner Akcam believes there is no room left for doubts about a centrally planned and instructed operation of annihilation and even, as he mentions, there was a division of labour among various organizations. He openly expresses the idea that, however amazing it may look, the reality that what happened in 1915 was a mass murder has been accepted by everybody having lived in that period, and can never be an object of argument. Highlighting the documented reality he insists that the extermination of Armenians had long become one of the national objectives of the Unionist leaders who had planned to avoid carrying out reforms in the eastern provinces and decided to solve the Armenian "problem" at its root. Moreover, Akcam reveals the falsity of the prevailing opinion about Turkey's forced entrance into the war. As he confirms, the Unionists, on the contrary, made great efforts to join the war, for they could well foresee the opportunities, the process of the World War I could avail them of. They expected they could manage to return the territories they had lost in the Balkan 
war and accomplish their grand project of Pan-Turanist and Pan-Islamic expansion (Akcam 2003; 2006).

However T. Akcam tries to take the responsibility off the shoulders of the Turkish people, intending to save the reputation of his people and holding the group of Unionists in charge. This intention of his is particularly enhanced by the dedication of his book to an ethnic Turk - Haji Halil who risking his own life, hid eight members of an Armenian family more than six months and saved them. Indeed a heroic deed, which really deserves praising ${ }^{2}$ ! But these are exceptional cases which can by no means level out the amount and grade of the atrocities (Gasparyan 2014:129-146).

We appreciate Taner Akcam's position of openly criticizing the 1915 felony and qualifying it as a genocide. We are also fully concordant with his belief that it was the idea of Pan-Turanism, we would say the insatiable itch of Pan-Turanism, that bothered the Turks. The striking proof of this were the clear statements made by Turkish authorities on different occasions, particularly that equality between Muslims and Christians was considered merely out of the question, and that the demographic character of the Empire should be exclusively Muslim, etc. Thus, we think, quite right are the scholars who would not confine their search of the "ideological roots" of the Armenian Genocide to the last quarter of the XIX and the first quarter of the XX centuries only, but also take into account the developments in the demographic trends of western Armenia in general from at least the end of the XV century on.

Thus, any attempt to search the causes of the Armenian Genocide in the "desperate" situation born out from the World War is just an escape from the reality, to say the least. The Young Turk Party conferences in Salonika in 1910 and 1911, where the question how to attain Muslim predominance had been discussed, come to prove that the Turkish authorities were, indeed, in search of possibilities to provide "territorial continuity" between Turks. This is also borne out by the fact of their instigating the actions in Baku in 1918, which clearly shows that Turks pursued the policy of extermination of Armenians beyond the borders of the Empire as well, namely in the north-western parts of Iran, in Nakhichevan and Eastern Transcaucasia ${ }^{3}$. The circumvention of this fact is simply impossible, for "in 1918 it was not the Turkish and Kurdish mob but the Turkish army that burnt down Armenian settlements and murdered the innocent inhabitants along the way to Baku and in Baku as well. Thus, the assertions of the Turkish side about the unreliability of Armenians being the actual reason for the deportations are completely false and fabricated, for the Armenians living in their historical lands in Nakhichevan and Eastern Transcaucasia were never a threat to Turkey. Moreover, they were not Ottoman citizens to be labeled as unreliable. However, they were even not deported, but slaughtered on the spot for one thing only - they were Armenians, i.e. Christians (Manasyan 2015:157-166).

Another fact of no less importance is that although in the initial phase of the Genocide Catholic Armenians were granted an exception, and this was because the Turks understood that Catholicism penetrated into Armenia from the Western countries, and 
they wouldn't prefer to hurt the feelings of the westerners, however this did not prevent them from breaking their promise and revoking the excepted cases once again. The Special Envoy Wolff Metternich's report on July 10, 1916 to Chancellor BethmannHollweg gives evidence of the fact that the Catholic and Protestant Armenians were eventually also being subjected to clearing up, although the Porte had repeatedly assured that the latter would not be deported. As he mentions referring to a reliable source, the last Armenians in Eregli (Arm. Aragil) and Siwas (Arm. Sebastia) had been completely cleared away, either deported, or Islamized or murdered, and there was not one Armenian sound to be heard anywhere.

The Austro-Hungarian Ambassador Pallavicini's report to the Foreign Minister Ottokar Czernin on December 22, 1917 once again confirms the Turk's religious fanaticism and the decisive role of Turkish religious expansionism underlying the execution of both the Armenian Genocide and the Genocide of other Christian national minorities. He writes that in Veren Shehir - a small town in the neighbourhood of Urfa (Arm. Urha, Yedesia) the population consisted of 1400 Armenian and 140 Assyrian families, the 400 of which were entirely exiled at the beginning of the summer. All the men were slaughtered. Rich families with women and children were exterminated. In the Diocese of Sgert (Arm. Sghert) there were 450 Armenian, 120 Caldian, 30 Jakobian families, all of which were pillaged, slaughtered or deported.

... Urfa, formerly Yedesia, king Abgar's capital had a more cruel fate. The Christian's, the number of which was above 25000, were cruelly pillaged, massacred and tortured three times, the quarters of the town were bombarded and destroyed. Their bishop and priests together with the prominent citizens of the town, nearly 500 people in number, were put into prison before being killed. ... they were exiled to Diarbekir but they were massacred on the way. Thousands of orphan slaves are now in Mohammedan families: great number of these unfortunates are starving in the streets of Urfa. The Mohammedans of Urfa together with the authorities personally took part in massacres, they looted the property of the Christians.

Reacting to numerous eyewitness accounts, British politician Viscount J. Bryce and historian Arnold J. Toynbee compiled statements from survivors and eyewitnesses from other countries including Germany, Italy, the Netherlands, Sweden, and Switzerland, who similarly attested to the systematized massacring of innocent Armenians by Ottoman government forces. In 1916, they published The Treatment of Armenians in the Ottoman Empire, 1915-1916, which, prior to its publication, was submitted to scholars (from Oxford University, Sheffield University and others) for verification, and they came to the conclusion that all the letters and reports were genuine and able to overpower any skepticism (Dadrian 1995:228). 
Today the Republic of Turkey denies the Genocide, although the systematic massacres are recognized as genocide by many countries and most scholars who have so far carried out an enormous number of different investigations, creating a profound mass of venerable literature. A great number of films have been shot, eyewitness testimonies and collections of documents published, and many facts so far unrevealed have been brought out to light. A great number of journalists, diplomats, soldiers, physicians, writers and missionaries from various European countries and the United States provide significant information about the systematic nature of the deportations and the subsequent massacres.

In fact, the Turkish desire of exterminating Armenians was not new at all. Kamil pasha as the head of the government (Grand Vizier of the Ottoman Empire from 1885 to 1891) expressed the idea that the way of solving the Armenian problem was the physical extermination of the people, more so as the regime had all necessary means for it: the Kurds, governors, judges, tax-collectors, police, in fact everything to wage, in his terms, a religious campaign against a nation which lacked high positions, arms and army, particularly since Britain - one of the world's greatest and richest powers, in fact, the master of the Asian World, was their ally (Khurshudian 1995:33) ${ }^{4}$.

The criminal intent to commit the large-scale Genocide in 1915 in the course of time took the form of a process of preparation of genocide by the supreme state bodies, and gradually grew into a state program. The existence of such a program adopted and approved by the supreme body of state authorities indicates that the Ottoman state faced a reality in which genocide was the manifestation of state policy. In these circumstances it becomes evident that April 24, 1915 is just a symbolic date to commemorate the victims of the Armenian Genocide.

Thus, we believe that one of the basic reasons for the decision and the acts of eradicating Armenians and Christians at large was the difference in religious identity and the strive of the Ottoman government for religious expansionism. All the facts adduced above reveal the actual intentions of the Ottoman state bodies whose ultimate goal was the annihilation of the Armenians, and deportations were just a link in the chain of events meant to extirpate the Armenian population out of the cradle of their origin and their civilization.

The mass killings, the exterminations that accompanied the deportations, the forcible "mass conversions" to Islam of Armenian children whose parents had been killed - all this was a very good cause to raise the indignation of the entire civilized world. But, alas, the civilized world preferred to be silent. This must be one of the main reasons why today, in the XXI century, when a 100 years have passed after the symbolic date of 1915, almost nothing has changed in the behaviour of today's governors of Turkey who, in fact gave all possible support to the terrorists in their attack upon the Christian population of Kessab, aiming to kill them or once again drive them out of their houses, thus forcibly deporting them from their province. This must be the reason why instead of regretting, instead of apologizing and repaying for the shameful acts pre-schemed 
and accomplished by their ancestors, they had chosen April 24, 2015 as a day for celebrating their victory in the battle of Galli Poli.

\section{Conclusion}

Summing up, we would like to stress out just a few very important ideas:

1. The deportation scheme was outlined to disguise the actual intents of the Turkish government.

2. There being absolutely no doubt about the reality of the Armenian Genocide not only for us - Armenians, but also the progressive part of the civilized world, the idea of paramount importance is that the fact of World War I, speculated by the rejectionists is just a pretext to conceal the far-going intentions of Turkey.

3. There can be no doubt that the fact of the Armenian Genocide must never be forgotten or ignored, for it is an evil challenging mankind as a whole. It requires internationally wide recognition and condemnation, so that to prevent the birth of other genocides.

\section{Notes:}

1. The documented information used in this article has been derived from the website of the Museum-Institute of the Armenian Genocide. Available at: $<$ http://genocidemuseum.am/eng $>$ [Accessed 17.02. 2014, 21:00]

2. The glory of this heroic stance was given by an Armenian - Mr. Greg Sarkisyan, at a conference in Armenia in 1995.

3. The collection of documents published under the title The Massacres of Armenians in the States of Baku and Elizavetopol in 1918-1920 (2003) and many other pieces of evidence confirm and ground this fact (Cf. Manasyan 2015).

1. There are reasons to believe that the Turkish conviction and determination of annihilating the Armenian population of western Armenia was encouraged and supported by the vicious thoughts expressed by Lawrence of Arabia - ...they are creative, harmless, thrifty, graceful, intelligent, gone forward... and just for these reasons they should be killed off. (Gasparyan N. T.E. Lawrence's Idea on How to Solve the Armenian Question. // Armenian Folia Anglistika. International Journal of English Studies. N1(12), Yerevan, 2014, pp. 171-177). Available at: $<$ http:/wwwfacebook.com/ajax/messaging/attachment.php?attach_id=credfa3ae532 $\mathrm{d} 48 \mathrm{~b} 72 \mathrm{f} 5 \mathrm{db} 1551009 \mathrm{eb} \& \mathrm{mid}=$ mid.1392185532567\%3A92b24ac853e53ac152\&hash $=$ AQA4PiftzRsJq9dD $>$ [Accessed 15.02. 2014, 21:20]. 


\section{References:}

1. Akcam, T. (2006) A Shameful Act: The Armenian Genocide and the Question of Turkish of Responsibility. New York: NY Metropolitan Books.

2. Akcam, T. (2003) 1915 Legends and Realities. // Radikal, May 25.

3. A.A. Türkei, 183/40, A36184 in Dadrian (1995)

4. Dadrian, V. (1995) The History of the Armenian Genocide: Ethnic Conflict from the Balkans to Anatolia to the Caucasus. Providence \& Oxford: Berghahn Books.

5. Gasparyan, N. (2014) T.E. Lawrence's Idea on How to Solve the Armenian Question // Armenian Folia Anglistika. International Journal of English Studies. N ${ }^{\mathrm{o}} 1(12)$, Yerevan, pp. 171-177.

6. Gasparyan, S. (2014) The Armenian Genocide: A Linguocognitive Perspective. Yerevan: YSU Press.

7. Khurshudian, L. (1995) Haykakan hartsy. Yerevan: YSU Press.

8. Manasyan, A. (2015) The Armenian Genocide: The International Political Boomerang of the Crime. // Armenian Folia Anglistika. / International Journal of English Studies. N ${ }^{0}$ 1(13). Yerevan: YSU Press, pp. 157-166.

9. Marshal Lang, D. (1980) Armenia: Cradle of Civilization. 3-rd edition, London: Unwin Hyman Ltd.

10. Melkonyan, A. (2015) The 1915 Mets Yeghern (Genocide) of Armenians: History and Contemporary Problems. // Armenian Folia Anglistika. / International Journal of English Studies. N ${ }^{\circ}$ 1(13), Yerevan: YSU Press, pp. 180-185.

11. Melvanzade, R. (1929) Tyurkie Inkilabynyn itch Yuzyu. 1-ci fasil. Halep.

12. Morgenthau, H. (1918) Ambassador Morgenthau's Story. New York: Page and Company.

13. Morgenthau, H. (1974) The Murder of a Nation. New York: Armenian Benevolent Union of America, INC Publishers.

14. Refik, A. (1919) Iki Komite Iki Kital. Istanbul: Tarih.

15. Sahakyan, L. (2011) Turkification of Toponyms in the Ottoman Empire and the Republic of Turkey. Montreal: Arod Publishers.

16. Sahakyan, L. (2015) Concerning the Identity of the Generations of Islamized Hamshen Armenians. // Armenian Folia Anglistika. / International Journal of English Studies. N 1(13). Yerevan: YSU Press, pp. 186-192.

17. Suny, R. (1993) Looking toward Ararat: Armenia in Modern History. Bloomington and Indianapolis: Indiana University Press.

18. (2011) Turkery turkeri masin. / Compiled and ed. by R. Melkonyan, Vol. III. Yerevan: YSU Press.

19. (1995) U.S. National Archives. R.G. 59.807.4014/148 in Dadrian. 
fnGip untquhuanıpjnıGitip. ¿mjuuunua - 1915p.

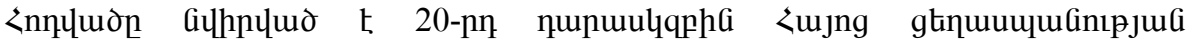

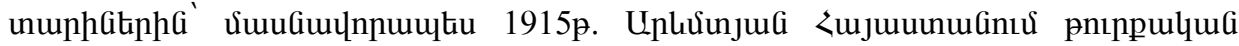

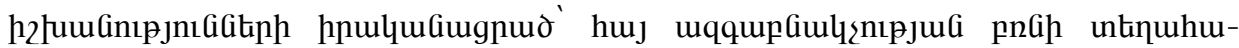

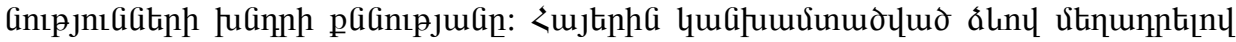

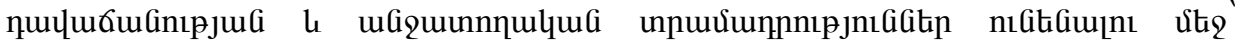

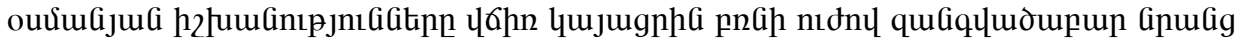

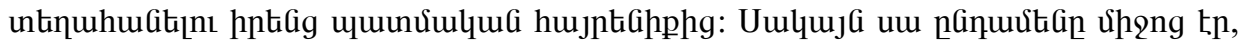

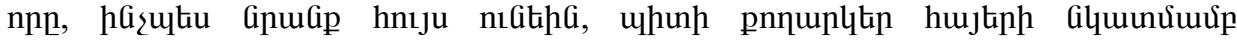

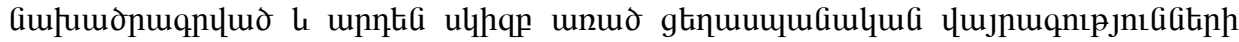

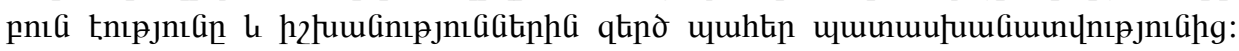

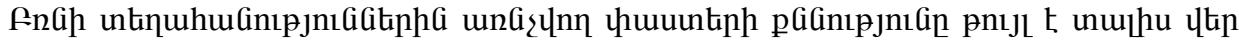

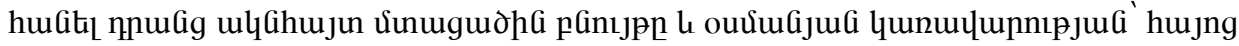

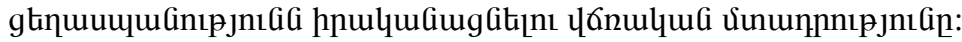

\section{Насильственная депортация - пример Армении 1915 года}

Исследование посвящено вопросу о насильственных депортациях армянского населения западной Армении в годы Геноцида армян в начале XX века. Умышленно обвиняя армян в предатльстве и сепаратистском настрое и прикрывая свой уже разработанный план уничтожения и окончательного искоренения армян из своих исконно армянских, но завоеванных турками земель, османские власти распорядились осуществить массовую депортацию армянского населения любой ценой. Анализ приведенных в статье фактов, свидетельствующих о полной безпомощности и безвыходности армян не только в восточных и юго-восточных провинциях империи, а также в сталице, позволяет выявить истинное намерение османского правительства - осуществить Геноцид армян под маской депортации. 